\title{
Environmental survey in relation to mining operations at Mârmorilik, Umanak district, central West Greenland
}

\section{Gert Asmund}

The mining company Greenex $\mathbf{A} / \mathrm{S}$ has been engaged in mining operations at Mârmorlik since August 1973. Since then tailings from the flotation plant have been dumped into the fjord Agfardlikavsâ. The environmental inpact of the approximate 450000 tons per year of waste containing lead and zinc has been investigated during complete ice cover in February 1974 and during an open water situation in September 1974. In cooperation with Grønlands Fiskeriundersøgelser samples of the fauna of the bottom sediments and of sea water were collected on both occasions. Seaweed and mussels were also collected in September. The chemical analyses were undertaken by GGU and the Institute for Petrology, University of Copenhagen.

The study represents the continuation of an earlier project in the same region (Bondam \& Asmund, 1974). A map of the Mârmorilik area showing details of bathymetry and sample localities was presented by these authors.

\section{Sediments}

Sampling of bottom sediments shows that the tailings, as anticipated, are concentrated in sediments only in Agfardlikavsâ. The February investigation indicated that only a few per cent pass the $21 \mathrm{~m}$ deep threshold between Agfardlikavsâ and the larger fjord Qaumarujuk.

\section{Sea water}

The content of dissolved lead and zinc in Agfardlikavsâ is considerable, compared to the trace element content in its natural state measured in 1972 and 1973 (Vandkvalitetsinstituttet, 1974). Already by February 1974 the dissolved zinc and lead content had increased to very high values in the entire volume of Agfardlikavsâ (station 1 and 2 in Table 1, and fig. 4 of Bondam \& Asmund, 1974). During the ice-free period represented by sampling in September, only the bottom mass of water was contaminated.

As shown in Table 1, stations 1 and 2, the dissolved lead content at the bottom rose to $1000-1100 \mathrm{ppb}$, while the dissolved zinc content increased to a level of 590$800 \mathrm{ppb}$.

The water is nearly saturated with oxygen, which means that dissolution is presumably caused by oxidation of the sulphides to sulphates. Again the threshold efficiently separates the contaminated Agfardlikavsâ water from the non-contaminated Qaumarujuk water. Stations 3-6 in Qaumarujuk all show insignificant influence from the disposal of tailings.

\section{Seaweed}

The seaweed was analysed by Haldis Bollingberg, Institute for Petrology. There was no detectable difference between seaweed collected before and after mining operations 
Table 1. Content of dissolved metals in sea water at Mârmorilik during February and September 1974

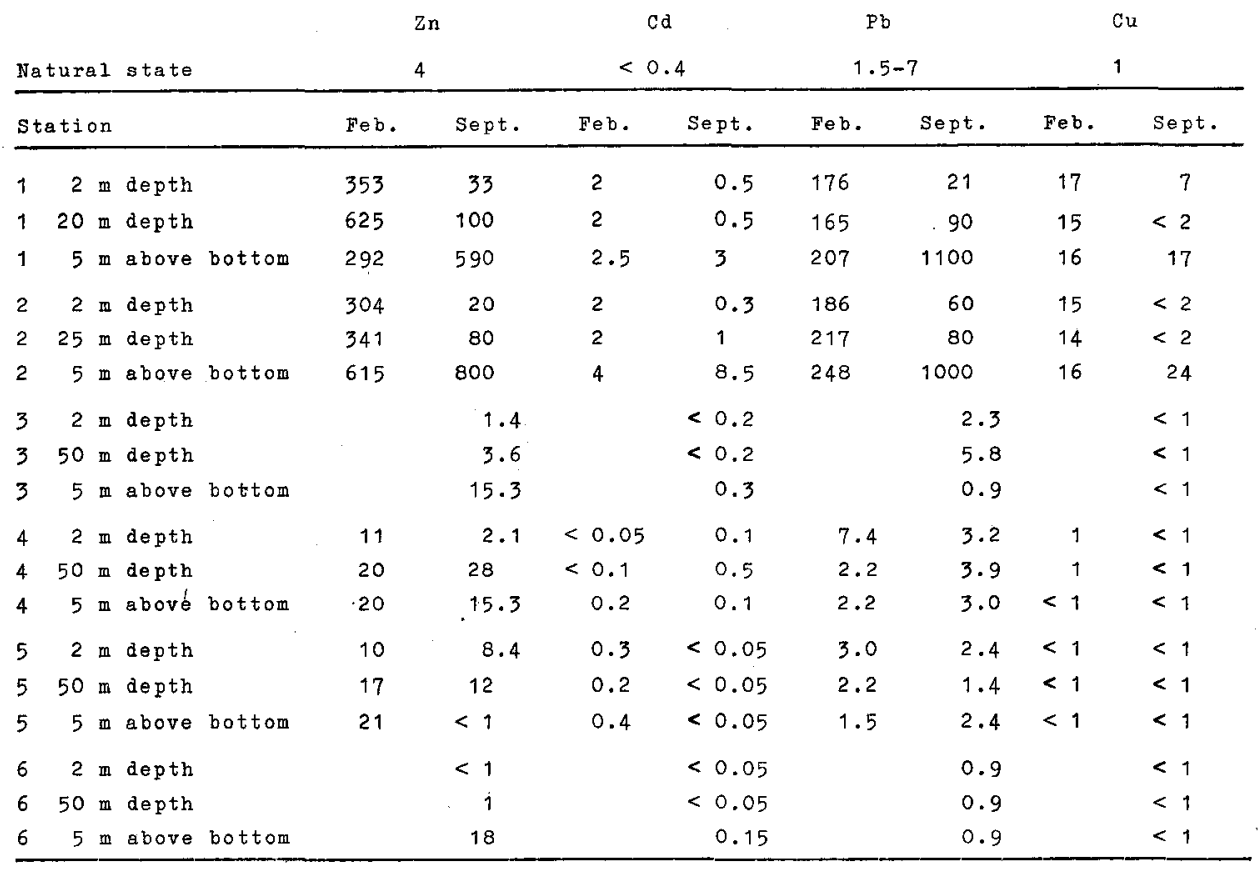

$\mathrm{ppb}=10^{-9}=\mathrm{mg}$ pr ton

had started, although seaweed is known to be a good collector of heavy metals. The explanation is probably that the surface water in the growing season is relatively uncontaminated.

\section{Cyanide}

Another environmental hazard, in addition to heavy metals, is provided by the flotation chemical sodium cyanide. The sodium cyanide content in the tailings water is usually below $1 \mathrm{ppm} ; 2 \mathrm{ppm}$ is the permitted limit. It was originally assumed that the added cyanide would be absorbed in the concentrates, but recent analyses have shown that a major part of the cyanide remains in the tailing water as dissolved thiocyanate. The concentration is on average $30 \mathrm{mg} \mathrm{SCN}^{-}$per litre of tailing water. Its environmental effect is little known, but it is believed to be much less toxic than cyanide.

\section{References}

Bondam, J. \& Asmund, G. 1974: Environmental studies in the Qaumarujuk and Agfardlikavsâ fjords, Umanak district, central West Greenland. Rapp. Grønlands geol. Unders. 65, 29-33.

Vandkvalitetsinstituttet 1974: Recipientundersøgelse, juli 1973, Qaumarujuk Fjord, Agfardlikavsâ. København: Vandkvalitetsinstituttet, ATV. 